\title{
SELEKSI SPERMATOZOA PADA FERTILISASI IN VITRO (IVF)
}

\author{
Amalia Shari \\ amaliashari.hermina@gmail.com, Politeknik Kesehatan Hermina
}

\begin{abstract}
In Vitro Fertilization (IVF) is the penetration of ovum cells by spermatozoa in a culture system and is a reproductive technique that is useful for increasing the efficiency of sperm and ovum utilization. In vitro fertilization is applied to overcome the problem of infertility and prevent of birth defects. This review article aims to summarize as well as analyze the beginning process in vitro fertilization is spermatozoa selection. The method used in writing this article is literature review study on the PubMed Central (PMC), Springer, and Open Access Science Direct databases. Journal articles that are in accordance with the theme of the review are then reviewed by paraphrasing the core and common threads of the research. The conclusion from this article review is that the success of IVF is determined by the quality of the spermatozoa. In order to fulfill this, it is necessary to select spermatozoa. Currently, the selection of spermatozoa can be reviewed by measuring the DNA damage to spermatozoa, in addition to the selection of spermatozoa based on morphology, motility, and concentration.
\end{abstract}

Keywords: spermatozoa selection, IVF, morphology, motility, DNA sperm.

\begin{abstract}
Abstrak
Fertilisasi in vitro (In Vitro Fertilization) merupakan penyatuan sel ovum dengan spermatozoa dalam suatu sistem kultur dan merupakan salah satu teknik reproduksi yang bermanfaat untuk meningkatkan efisiensi pemanfaatan spermatozoa serta ovum. Fertilisasi in vitro (IVF) diterapkan untuk mengatasi persoalan infertilitas serta pencegahan terhadap kelahiran bayi cacat .Penulisan artikel ini bertujuan untuk merangkum sekaligus menganalisa awal mula seleksi spermatozoa pada fertilisasi in vitro. Metode yang dilakukan dalam penulisan artikel ini dengan cara studi literatur pada database PubMed Central (PMC), Springer, dan Open Access ScienceDirect. Artikel jurnal yang sesuai dengan tema review kemudian ditelaah dengan cara memparafrasa kembali inti dan benang merah dari penelitian tersebut. Hasil penelitian adalah keberhasilan IVF salah satunya ditentukan oleh kualitas spermatozoa, dalam rangka memenuhi hal tersebut perlu dilakukan seleksi spermatozoa, saat ini seleksi spermatozoa dapat ditinjau dengan pengukuran kerusakan DNA sepermatozoa, disamping seleksi spermatozoa berdasarkan morfologi, motilitas, dan konsentrasi.
\end{abstract}

Kata kunci : seleksi spermatozoa, IVF, morfologi, motilitas, DNA sperma.

\section{PENDAHULUAN}

Bersatunya spermatozoa dengan ovum dinamakan peristiwa fertilisasi. Spermatozoa dan ovum berasal dari dua individu yang berbeda, kedua sel ini harus melalui perjalanan yang relatif panjang. Spermatozoa dan ovum mengalami berbagai macam proses persiapan dan daerah pertemuan juga harus memenuhi syarat agar spermatozoa dan ovum dapat dengan mudah bertemu dan bersatu (Respati, 2015).

In Vitro Fertilization (IVF) merupakan salah satu teknik reproduksi berbantu pada manusia yang sedang berkembang. IVF merupakan suatu teknik penembusan sel ovum oleh spermatozoa dalam suatu sistem kultur dan merupakan salah satu teknik reproduksi yang berguna untuk meningkatkan efisiensi pemanfaatan sperma dan ovum. Spermatozoa dan ovum dipertemukan di dalam sebuah tabung atau cawan petri dengan diberikan perlakuan khusus terlebih dahulu sehingga dapat terjadi fertilisasi, In vitro fertilisasi diterapkan untuk mengatasi masalah infertilitas dan pencegahan terhadap kelahiran bayi cacat (Respati, 2015).

Produksi embrio secara IVF melalui tiga tahap, yaitu pematangan oosit, pembuahan oosit, dan kultur embrio. Faktor keberhasilan IVF dengan indeks prediksi tertinggi yaitu kualitas spermatozoa terdiri dari morfologi, motilitas dan persentase sperma dengan akrosom 
utuh. Dalam rangka memenuhi hal tersebut perlu dilakukan seleksi spermatozoa, spermatozoa berkualitas baik dipisahkan dari total populasinya (Walters, A.H dkk, 2004).

Menurut WHO spermatozoa yang berkualitas yaitu spermatozoa yang mempunyai daya hidup tinggi, morfologi yang normal dan motilitas yang progresif. Motilitas merupakan kemampuan gerak maju spermatozoa di dalam lingkungan zat cairnya. Pergerakan tersebut penting untuk membantu spermatozoa menembus sel-sel pelindung yang mengelilingi ovum (Sujoko dkk, 2009 \& Tomsu dkk, 2002). Penulisan ini bertujuan untuk merangkum sekaligus menganalisa awal mula seleksi spermatozoa pada fertilisasi in vitro dan mengetahui kriteria sperma dengan kualitas yang baik untuk menunjang proses fertilisasi in vitro.

\section{METODE}

Artikel review ini bertujuan untuk merangkum literatur-literatur yang berhubungan dengan seleksi spermatozoa untuk proses IVF. Penulisan artikel review dilakukan dengan metode literatur review dengan cara merangkum sekaligus menganalisis metode seleksi spermatozoa untuk proses IVF. Artikel yang ditelaah diperoleh dengan cara pencarian pada jurnal-jurnal internasional berbahasa inggris pada PubMed Central (PMC), Springer, dan Open Access ScienceDirect. Pencarian dilakukan dengan kata kunci "Spermatozoa Selection", "In Vitro Fertilization", "Morphology spermatozoa", "Motility of spermatozoa”, dan "DNA spermatozoa".

\section{HASIL DAN PEMBAHASAN}

\section{Sejarah Mikro Injeksi}

Pada awal abad ke-20 beberapa teknik manipulasi mikro yang secara ekslusif diterapkan pada sel hidup telah berkembang. Seorang ilmuan yang bernama Kite pada tahun 1911, telah berhasil memisahkan pronukleus yang baru terbentuk pada zigot menggunakan jarum mikro. Selanjutnya Kite berpikir tentang apa yang akan terjadi bila spermatozoa diinjeksikan secara langsung ke dalam sel ovum. Kemudian Pemikiran tersebut diwujudkan dengan menginjeksikan dua hingga dua belas spermatozoa ke sebuah sel ovum namun tak satupun sel ovum terbuahi (Saili dkk, 2005).

Beberapa alat yang menunjang untuk pengerjaan manipulasi mikro telah berhasil dibuat antara lain joystick oleh Emmerson pada tahun 1928, secara langsung dapat mengatur pergerakan alat manipulasi mikro sesuai keinginan operator. Alat ini selanjutnya dikembangkan oleh De Fonbrune pada tahun 1928 menggunakan prinsip hidrolik. Selain itu De Fonbrune pada tahun 1934 juga menciptakan alat microforge yang masih tetap dipergunakan oleh banyak peneliti hingga sekarang. Teknik manipulasi mikro telah berkermbang secara bertahap lebih dari satu abad dan sudah mencapai tingkat keberhasilan hingga para peneliti telah mampu memotong sebuah kromosom tunggal (Saili dkk, 2005).

\section{Spermatogenesis}

Reproduksi pria menghasilkan sel spermatozoa. Sel tersebut mempunyai bentuk spesifik yang terdiri atas kepala, leher dan ekor. Spermatozoa adalah sel hasil maturasi dari sel epitel germinal yang disebut spermatogonia. Spermatogonia terletak dalam dua sampai tiga sepanjang lapisan batas luar epitel tubulus. Proses perkembangan spermatogonia menjadi 
spermatozoa disebut spermatogenesis. Proses spermatogenesis terjadi di dalam tubulus seminiferus selama kehidupan seksual aktif. Proses tersebut terjadi akibat dari rangsangan oleh hormon gonadotropin yang dihasilkan oleh hipofisis anterior dan dimulai rata-rata pada usia 13 tahun dan berlangsung sepanjang hidup (Wododo dkk, 2005).

Pada tahap pertama dari spermatogenesis, spermatogonia primitif berkumpul tepat di tepi membran basal dari epitel germinativum, disebut spermatogonia tipe A, membelah empat kali untuk membentuk 16 sel yang lebih berdiferensiasi, yaitu spermatogonia tipe B. Pada tahap ini, spermatogonia bermigrasi ke arah sentral di antara sel-sel Sertoli. Sel-sel Sertoli mempunyai membran yang sangat kuat berlekatan satu sama lain pada bagian dasar dan bagian sisi, sehingga dapat membentuk suatu lapisan pertahanan yang mencegah dari peneterasi dari kapiler-kapiler yang mengelilingi tubulus. Namun spermatogonia yang sudah dipersiapkan untuk menjadi spermatozoa dapat menembus lapisan pertahanan tersebut (Wododo dkk, 2005).

Proses berikutnya ialah pembelahan secara meiosis. Dalam waktu 24 hari, setiap spermatogonium yang masuk ke dalam lapisan sel-sel sertoli dimodifikasi secara berangsurangsur dan membesar untuk membentuk suatu spermatosit primer. Pada akhir hari ke-24, setiap spermatosit membelah menjadi dua spermatosit sekunder. Pembelahan ini disebut sebagai pembelahan meisosis pertama. Pada tahap awal pembelahan meiosis ini, semua DNA dalam 46 kromosom bereplikasi. Dalam proses ini, masing-masing 46 kromosom menjadi dua kromatid yang tetap berikatan bersama pada sentromer, kedua kromatid memiliki gen-gen duplikat dari kromosom tersebut. Pada waktu ini, spermatosit primer membelah menjadi dua spermatosit sekunder, yang setiap kromosom berpisah sehingga ke-23 kromosom, yang masing-masing memiliki dua kromatid, pergi ke salah satu spermatosit sekunder sementara 23 kromosom yang lain pergi ke spermatosit sekunder lainnya. Dalam dua sampai tiga hari, pembelahan meiosis kedua terjadi, di mana kedua kromatid dari 23 kromosom berpisah pada sentromer, membentuk dua pasang 23 kromosom, satu pasang terdapat dalam satu spermatid dan satu pasang yang lain terdapat pada spermatid kedua (Wododo dkk, 2005).

Beberapa minggu berikutnya setelah tahap pembelahan meiosis, setiap spermatid kembali dimodifikasi oleh sel-sel sertoli secara mengubah spermatid perlahan lahan menjadi suatu spermatozoa dengan cara menghilangkan beberapa sitoplasmanya, mengatur kembali bahan kromatin dari inti spermatid untuk membentuk satu kepala spermatozoa yang padat, dan mengumpulkan sisa sitoplasma dan membran sel pada salah satu ujung dari sel untuk membentuk ekor. Bentuk akhir spermatozoa terdiri atas kepala, dan ekor (Wododo dkk, 2005). 


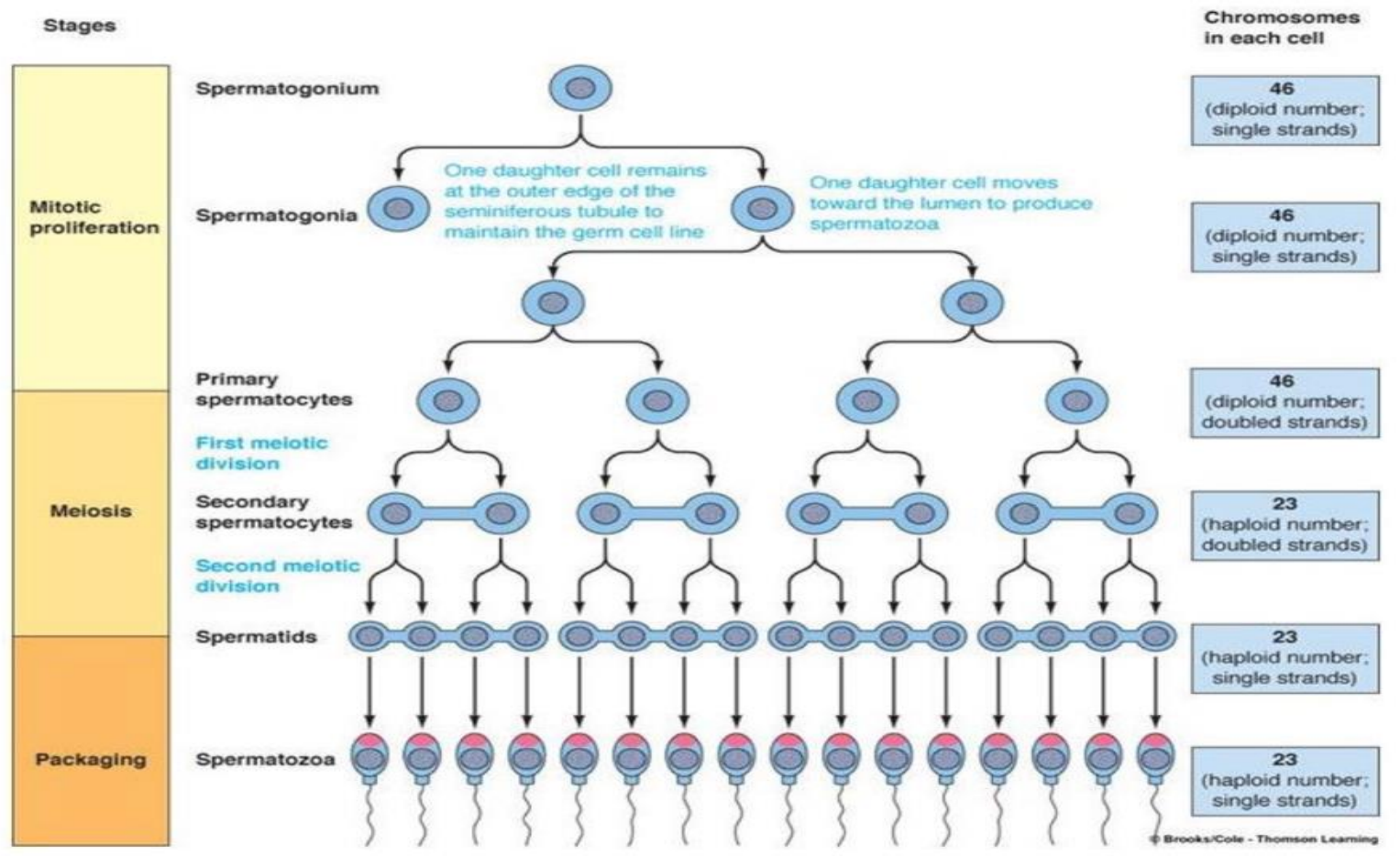

Gambar 1. Proses spermatogenesis (Sherwood, 2012)

\section{Seleksi Spermatozoa}

Seleksi spermatozoa dapat dilakukan dengan mengetahui kualitas spermatozoa dan kerusakan DNA sperma.

\section{Kualitas spermatozoa}

Ciri-ciri spermatozoa yang berkualitas, yaitu mempunyai daya hidup tinggi, morfologi normal dan motilitas progresif. Spermatozoa normal memiliki tiga bagian yaitu kepala, leher, dan ekor. Bila salah satu bagian tersebut tidak ada atau bentuknya abnormal menyebabkan kemampuan sel sperma untuk membuahi sel ovum menjadi menurun. Sperma dianggap normal jika bentuk sperma normal sekitar 30\% dari tiap ejakulat (Respati, 2015).

Morfologi Sperma

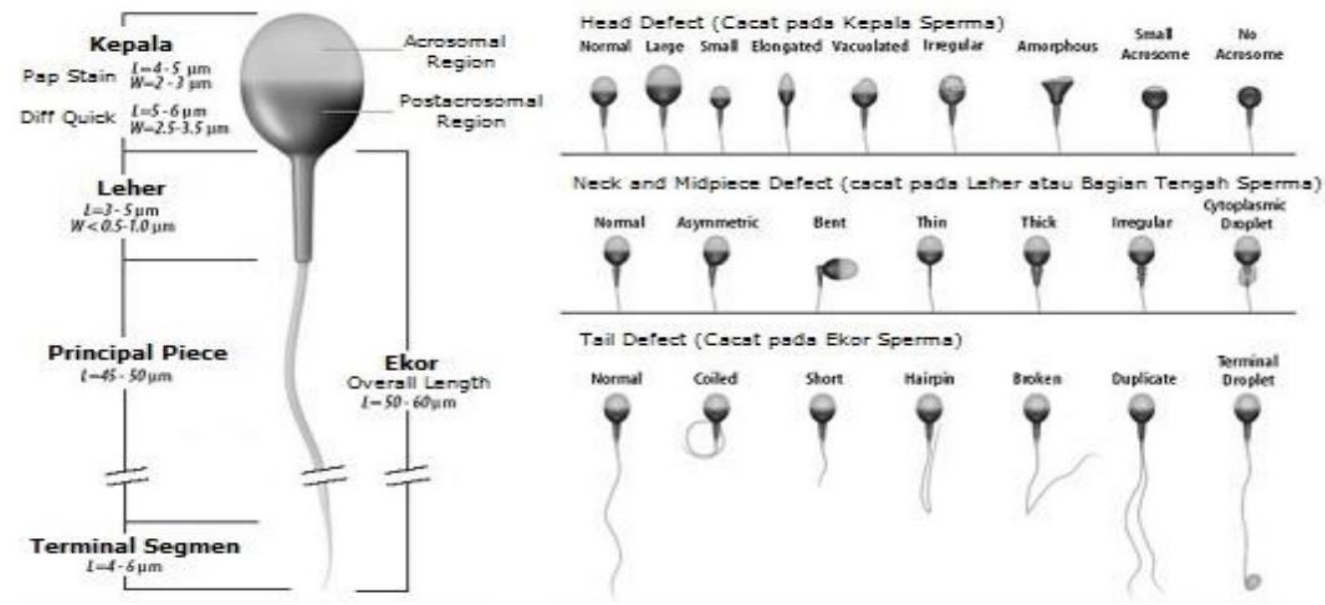


Gambar 2. Morfologi spermatozoa dewasa (WHO Guideline, 2010 )

Motilitas merupakan kemampuan gerak maju spermatozoa di dalam lingkungan zat cair. Pergerakan tersebut penting dalam membantu spermatozoa menembus sel-sel pelindung yang mengelilingi sel ovum. Jenis motilitas spermatozoa tergantung dari gerakan ekor, kemajuan, arah, dan kecepatan spermatozoa (Sujoko, 2009).

WHO 2010 manual, merekomendasikan penggunaan sistem yang sederhana untuk pengelompokan motilitas yang membedakan spermatozoa dengan motilitas progresif atau non progresif dari yang bersifat immotil. Motilitas setiap spermatozoa dapat dikelompokkan sebagai berikut: (1) Motilitas progresif (PR): spermatozoa bergerak aktif, baik secara linear atau dalam lingkaran besar, terlepas dari kecepatan spermatozoa itu sendiri; (2) Motilitas nonprogresif (NP): semua pola lain dari motilitas dengan ketiadaan progresif, misalnya berenang di lingkaran kecil atau ketika flagella hanya bergetar yang dapat diamati; (3) Immotility (IM): tidak ada gerakan (Franken dkk, 2012).

Motilitas spermatozoa dapat dipertahankan dengan adanya hormon prolaktin PRL. Munculnya hormon ini tidak hanya menekan kapasitasi tapi juga memperpanjang motilitas spermatozoa (Pujianto dkk, 2010). Motilitas spermatozoa sangat rentan dengan perubahan kondisi lingkungan. Sewaktu penampungan harus diperhatikan agar ejakulat tidak mengalami penurunan suhu secara mendadak (cold shock) yang sangat mempengaruhi motilitas spermatozoa. Panas yang berlebih-lebihan dan bahan-bahan kimia atau benda asing lainnya juga dapat menurunkan motilitas spermatozoa (Widodo dkk, 2005). Syarat minimal konsentrasi spermatozoa untuk IVF adalah 1 juta sel $/ \mathrm{ml}$, motilitas progresif $40 \%$, spermatozoa hidup $40 \%$ dan abnormalitas kurang dari 14\% (Sujoko dkk, 2009).

\section{Tes Kerusakan DNA sperma}

Penyebab kerusakan DNA sperma ini sebagian besar tidak diketahui, meskipun ada bukti yang menunjukkan bahwa cacat genetik mungkin mendasari beberapa kerusakan DNA sperma. Berbagai tes telah dikembangkan untuk mengukur kerusakan DNA sperma, seperti tes pewarnaan acridine orange, SCSA, Comet dan TUNEL assay. Comet dan TUNEL assays, mendeteksi kerusakan DNA yang sebenarnya. Pendekatan lain mengukur kerentanan denaturasi DNA, yaitu pembentukan DNA beruntai tunggal dari DNA beruntai ganda. Pendekatan ini tergantung pada fakta bahwa DNA yang terdenaturasi lebih mudah daripada DNA beruntai ganda. Beberapa tes bergantung pada pengikatan pewarna yang berbeda untuk DNA beruntai tunggal dan DNA beruntai ganda (Zini dkk, 2009).

Comet assay mengukur kerusakan DNA dengan kuantifikasi single-stranded dan double-stranded breaks yang dikaitkan dengan kerusakan DNA. Dalam pengujian ini, spermatozoa yang diwarnai dengan pewarna fluorescent DNA-binding. Gambar yang dihasilkan menyerupai "komet", yang diukur setelah pewarnaan untuk menentukan tingkat kerusakan DNA. Karakteristik yang telah digunakan untuk analisis meliputi diameter nucleus dan panjang komet. Salah satu prinsip dari comet assay adalah bahwa potongan doublestranded DNA cenderung untuk tetap berada di kepala komet, sedangkan fragmen pendek dari potongan DNA double-stranded dan single-stranded pindah ke area ekor. Dengan demikian, spermatozoa dengan tingkat tinggi dari DNA strand breaks akan menunjukkan peningkatan 
intensitas fluorescent ekor komet dan panjang ekor komet. Namun, ambang batas yang berguna belum ditetapkan untuk comet assay (Agarwal, 2003).

In-situ nick translation (NT) assay mengkuantifikasi penggabungan biotinylateddeoxyuridine trifosfat (dUTP) pada single-stranded DNA breaks dalam reaksi yang dikatalisis oleh enzim template-dependent, DNA polimerase I. NT assay akan mengidentifikasi spermatozoa yang mengandung kadar cukup dan variabel endogen kerusakan DNA. Nilai klinis dari NT assay sangat terbatas karena tidak ada korelasi yang telah terbukti dengan fertilisasi selama di-vivo, dan karena kurangnya sensitivitas dibandingkan dengan tes lainnya (Agarwal, 2003).

TUNEL assay mengkuantifikasi penggabungan deoxyuridine trifosfat (dUTP) pada single-stranded dan double-stranded DNA breaks dalam reaksi yang dikatalisis oleh enzim template-independent, terminal deoxynucleotidyl transferase (TdT). dUTP yang telah digabung diberi label sehingga DNA breaks bisa diukur dengan flow cytometri, mikroskop fluorescent atau mikroskop cahaya (Agarwal, 2003).

SCSA merupakan flow cytometric assay yang bergantung pada fakta kromatin sperma abnormal yang sangat rentan terhadap induksi fisik dari denaturasi DNA parsial in situ. Tingkat denaturasi DNA setelah perlakuan panas atau asam, ditentukan dengan mengukur pergeseran metachromatic dari fluoresensi hijau (acridine orange diselingi menjadi double-stranded asam nukleat) menjadi fluoresensi merah (acridine orange terkait dengan DNA single-stranded). Parameter yang paling penting dari SCSA adalah fragmentasi DNA index (\% DFI), yang mewakili populasi sel dengan kerusakan DNA (Agarwal, 2003).

Acridine orange test (AOT) diperkenalkan sebagai metode mikroskopis sederhana seperti SCSA yang tidak memerlukan peralatan flow cytometry mahal dan teknisi SCSA terlatih. Hal ini bergantung pada interpretasi visual dari fluorescing spermatozoa dan butiran yang jatuh ke dalam berbagai warna di bawah pemeriksaan mikroskopis. Warna tidak jelas, pelebaran fluoresensi secara cepat memudar dan pewarnaan bergeser secara heterogen memperburuk masalah dengan interpretasi. Kondisi tersebut menghalangi penggunaan AOT untuk diagnosis klinis kritis dan prognosis dari sampel semen, karena AOT dapat mengenal banyak sumber variasi. Meskipun beberapa laboratorium telah menggunakan AOT dalam upaya untuk meningkatkan evaluasi fertilitas laki-laki, nilai prediktif dari tes untuk fertilitas manusia masih kontroversi. Namun, dalam kaitannya dengan signifikansi klinis pengujian ini, terdapat korelasi positif yang kuat antara AOT dan tes TUNEL. Selain itu, AOT berkorelasi negatif dengan motilitas sperma (Agarwal, 2003).

Sperm chromatin dispersion (SCD) test, uji ini baru-baru ini digambarkan sebagai sebuah metode yang sederhana dan murah untuk analisis fragmentasi DNA sperma. Tes SCD didasarkan pada prinsip bahwa sperma dengan DNA terfragmentasi gagal menghasilkan karakteristik halo bila dicampur dengan aqueous agarose berikut denaturasi asam dan penghapusan protein nuklear (Agarwal, 2003).

Meskipun setiap tes mengukur kerusakan DNA secara berbeda, pada umumnya berkorelasi baik dengan satu sama lain (terkecuali tes pewarnaan orange acridine) dan tes itu juga umumnya berkorelasi terbalik dengan konsentrasi sperma. Secara umum, kerusakan DNA signifikan jarang ditemukan pada laki-laki fertil, dan insidensi kerusakan DNA lebih tinggi 
pada pria infertil. Penelitian terbaru menunjukkan bahwa tingkat kerusakan DNA sperma dapat memprediksi kemungkinan keguguran berulang (Dolores, 2010).

Sejumlah penelitian telah menguji pengaruh integritas DNA sperma pada tingkat kehamilan setelah IVF standar. Sebuah tinjauan sistematis dan meta-analisis IVF penelitian menunjukkan bahwa kerusakan DNA sperma dikaitkan dengan tingkat kehamilan IVF rendah dengan gabungan OR 1,57 (95\% CI, 1,18-2,07, P, 05). (Zini, 2009).

\section{PENUTUP}

Saat ini fertilisasi in vitro (IVF) dijadikan salah satu cara untuk mengatasi persoalan infertilitas. Keberhasilan IVF salah satunya ditentukan oleh kualitas spermatozoa, maka dari itu dalam rangka memenuhi hal tersebut perlu dilakukan seleksi spermatozoa. Seleksi spermatozoa dilakukan dengan cara memisahkan spermatozoa berkualitas baik dari total populasi. Kualitas spermatozoa dilihat dari morfologi spermatozoa, motilitas spermatozoa dan konsentrasi spermatozoa. Seleksi spermatozoa dapat ditinjau juga menggunakan pengukuran kerusakan DNA sepermatozoa. Saat ini pengukuran kerusakan DNA telah berkembang, seperti dengan teknik tes pewarnaan acridine orange, SCSA, Comet, serta TUNEL assay.

\section{DAFTAR PUSTAKA}

Agarwal, A. and Tamer M.Said. (2003). Role of sperm chromatin abnormalities and DNA damage in male infertility. Human Reproduction Update. 9(4): 331-345.

Franken, D.R., Sergio O. (2012). Semen Analysis and Sperm Function Testing. Asia Journal of Andrology. 14: 6-13.

Lamb, Dolores J. (2010). Semen Analysis in $21^{\text {st }}$ Century Medicine: The Need for Sperm Function Testing. Asia Journal of Andrology. 12: 64-70.

Pujianto, D.A., Curry, B.J., and Aitken, R.J. (2010). Prolactin Exerts a Prosurvival Effect on Human Spermatozoa via Mechanisms that Involve the Stimulation of Akt Phosphorilation and Supression of Caspase Activation and Capacitation. Endocrinology. 151(3): 1269-1279.

Respati, Giri. (2015). Keberhasilan Program Fertilisasi In Vitro di Klinik Infertilitas FK UndipRS Dr. Kariadi dan RS Telogorejo Semarang [tesis]. Semarang: Pendidikan Dokter Spesialis Obstetri dan Ginekologi. Universitas Diponegoro.

Saili, T., et.al. (2005). Intracytoplasmic Sperm Injection (ICSI) as an Advanced Assisted Reproductive Technology. J.Sain.Vet. 1: 53-59.

Sherwood, L. (2012). Fisiologi Manusia. Edisi 6, EGC : Jakarta, Halaman 211-224

Sujoko, H., Setiadi, M.A., and Boediono, A. (2009). Selection of Garut Sheep Sperms Using Percoll Density Gradient Centrifugation Method. Veteriner. 10(3): 125-132.

Tomsu, M., Sharma, V., and Miller, D. (2002). Embryo Quality and IVF Treatment Outcomes may Correlate with Different Sperm Comet Assay Parameters. Human Reproduction. 17(7): 1856-1862.

Walters, A.H., et.al. (2004). Sperm Morphology and Preparation Method Affect Bovine Embryonic Development. Journal of Andrology. 25(4): 554-563. 
WHO. (2010). WHO laboratory manual for the examination and processing of human semen, $5^{\text {th }}$ ed. Switzerland: WHO Press.

Widodo, F.T. (2005). Hubungan Antara Jumlah Leukosit Dengan Motilitas Sperma pada Hasil Analisa Sperma Pasien Infertilitas Di RSUP Dr Kariadi Semarang [laporan akhir penelitian]. Semarang: Program Pendidikan Sarjana Fakultas Kedokteran Universitas Diponegoro.

Zini, Armand, and Mark Sigman. (2009). Review Are Tests of Sperm DNA Damage Clinically Useful? Pros and Cons. Journal of Andrology. 30(3): 219-229. 